\title{
IMPROVING THE ABILITY OF MATHEMATIC PROBLEM SOLVING, MATHEMATIC CONNECTION AND SELF REGULATED LEARNING WITH JUNIOR HIGH SCHOOL STUDENTS THROUGH METAKOGNITIVE APPROACH
}

\author{
Asep Sopian ${ }^{1}$, Jozua Sabandar ${ }^{2}$ \\ ${ }^{1}$ SMPN 2 Jayakerta, Karawang \\ 2 IKIP Siliwangi, Bandung \\ ${ }^{1}$ asepsopian099@gmail.com, ${ }^{2}$ jsabandar@yahoo.com,
}

Received: June, 2018; Accepted: June, 2018

\begin{abstract}
This study is a quasi experiment, aiming to describe the level of achievement of problem solving abilities, mathematical connections of students and the independence of junior high school students through metacognitive approach. The sample was chosen randomly from the class of all students of class IX in one of SMP Negeri in Karawang regency. The two class samples were chosen as control and experiment classes. Each of us uses a set of problem solving and mathematical connection tests and a set of learning independence scales. The study found that the attainment and improvement of problem solving ability and mathematical connection ability of students using metacognitive approach is better than the students whose learning is using normal learning in terms of the students' initial ability level. While different from the independence of students who learn learning using metacognitive approach is not better than students who use regular learning in terms of initial ability level of students. However, there is no interaction between the metacognitive approach and the student's initial ability level in generating problem solving skills and mathematical connections as well as learning independence which means that increased problem solving abilities and mathematical connections are largely influenced by the metacognitive approach.
\end{abstract}

Keywords: Mathematical Problem Solving, Mathematical Connection, Self Regulated Learning, Metacognitive Approach

\begin{abstract}
Abstrak
Penelitian ini merupakan kuasi eksperimen, bertujuan untuk mendeskripsikan tingkat capaian kemampuan pemecahan masalah, koneksi matematis siswa dan kemandirian belajar siswa SMP melalui pendekatan metakognitif. Sampel dipilih secara acak kelas dari populasi seluruh siswa kelas IX di salah satu SMP Negeri di kabupaten Karawang. Adapun sampel dua kelas dipilih sebagai kelas kontrol dan eksperimen. Digunakan masing-masing satu set tes uraian pemecahan masalah dan koneksi matematik dan satu set skala kemandirian belajar. Penelitian menemukan bahwa pencapaian dan peningkatan kemampuan pemecahan masalah dan kemampuan koneksi matematik siswa yang menggunakan pendekatan metakognitif lebih baik dari siswa yang pembelajarannya menggunakan pembelajaran biasa ditinjau dari tingkat kemampuan awal siswanya. Sedangkan berbeda dengan kemandirian belajar siswa yang pembelajarannya menggunakan pendekatan metakognitif tidak lebih baik dari siswa yang menggunakan pembelajaran biasa ditinjau dari tingkat kemampuan awal siswanya. Akan tetapi tidak terdapat interaksi antara pendekatan metakognitif dan tingkat kemampuan awal siswa dalam menghasilkan kemampuan pemecahan masalah dan koneksi matematik serta kemandirian belajar yang artinya peningkatan kemapuan pemecahan masalah dan koneksi matematik lebih besar dipengaruhi oleh pendekatan metakognitif.
\end{abstract}

Kata Kunci: Pemecahan Masalah Matematik, Koneksi Matematik, Kemandirian Belajar, Pendekatan Metakognitif 
How to Cite: Sopian, A., Subandar, J. (2018) . Improving The Ability Of Mathematic Problem Solving, Mathematic Connection And Self Regulated Learning with junior high School Students Through Metakognitive Approach. JIML, 1 (2), 44-50.

\section{INTRODUCTION}

The purpose of mathematics learning according to Permendiknas No. (2) communicating ideas with symbols, tables, diagrams or other concepts other media to clarify circumstances or problems, (3) have an attitude of appreciating the usefulness of mathematics in life, that is to have curiosity, attention and interest in learning mathematics, as well as a tenacious attitude and confidence in problem solving.

Furthermore, NCTM (NCTM, 2000) explains that there are six important capabilities in learning mathematics, namely conceptual understanding, problem solving, reasoning and proof, communication, connection, , and representation.

The ability of mathematical connections is important but students who master mathematical concepts are not smart in mathematics. In a study it was found that students were often able to register mathematical concepts related to real problems, but few students were able to explain why the concept was used in the application (Lembke and Reys 1994, cited Berges on, 2000). Thus the ability of connections need dilatihkan to students. If students are able to link mathematical ideas then their mathematical understanding will deepen and last longer as they are able to see interrelationships between topics in mathematics, with contexts other than mathematics, and with the experience of daily living (NCTM, 2000) While, (Hariwijaya, 2009) states that the ability of mathematical connections need to be trained to students at school. Even the learning of mathematics will be more meaningful with the emphasis on the linkage between mathematical concepts with everyday life or other disciplines.

The ability to solve problems is very important in mathematics, not only for those who will later learn or study mathematics but also for those who will apply it in other fields of study and in everyday life (Russefendi, 2006) Sumarmo (Fauziah, 2010) states that problem solving is so important that it becomes a general goal of teaching mathematics even as the heart of mathematics. The process of thinking in problem solving requires the ability to organize strategy. This will train students to think critically, logically, creatively which is indispensable in dealing with the development of society (Sumarmo, 2006)

Affective aspect is also important to be enhanced is the independence of learning in supporting the success of student learning. Sumarmo (2010) states that individuals who have high learning independence tend to learn more actively, able to monitor, evaluate, and organize learning more effectively that saves time in completing their tasks, manage learning time efficiently and get the highest score in science. Thus, the independence of learning is an important thing that needs to be improved to support the success of student learning. According to (Bergeson, 2000) argued that the independence of learning is self-awareness, self-propelled, learning ability to achieve its goals.

This means that the ability to connect and solve mathematical problems and student learning independence is an important component that should be involved in the overall learning process. Seeing the importance of involving the process of independence in learning, it is necessary for us to use mathematics learning that involves the process of student learning independence to improve the ability of connections and solving student mathematical 
46 Sopian, A., Subandar, J. Improving The Ability Of Mathematic Problem Solving, Mathematic Connection And Self Regulated Learning with junior high School Students Through Metakognitive Approach.

problems. One of the learning alternatives that involves students' way of thinking consciously is learning with a metacognitive approach

(Permata, Suherman, \& Rosha, 2012)) adds that metacognitive learning-oriented problemsolving is believed to make learning more meaningful and students' understanding deeper. In addition, the problem-oriented metacognitive model is also very potential to produce learners who have high-level mathematical competence beyond conventional learning, because every cognitive process that is stimulated through the learning process is accompanied by thinking activities to plan, monitor and reflect the entire cognitive process that occurs, so that what is done can be controlled optimally. Through this ability a person may have a high level of ability in problem solving.

Metacognitive learning invites students to develop their learning concepts. Students are able to recognize the importance of mastery of a mathematical ability, train their independence to learn, and enable students to recognize their shortcomings and strengths, so as to exercise control over their knowledge. Therefore, based on the above explanation the researcher intends to examine the influence of the use of metacognitive approach in learning mathematics to the achievement of connection ability and solving mathematical problems and student learning independence.

\section{METHOD}

This research method is quasi experiment where researcher take two classes as sample of research. The first class gets a metacognitive approach while the second class gets regular learning. Before and after the treatment of both classes were given a parallel test that is the ability to solve problems and mathematical connections. The design of this research is (Sugiono, 2013)

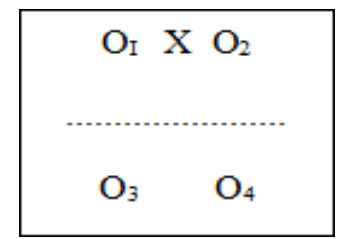

O : Pretest and posttest troubleshooting capabilities and mathematical connections

$\mathrm{X} \quad$ : Treatment with a metacognitive approach

: No random sampling of subjects

Population in this research is all student of SMP with subject of sample is two class of student of class IX in one of State Junior High School in Kabupaten Karawang.

Instruments in this research are:Soal Tes Kemampuan Pemecahan Masalah Matematis

1. Mathematical Connection Test Problems

2. Questionnaire or attitude scale to measure learning independence

Intrumen test in the form of test questions description of the ability konekai and solving mathematical problems concerning the indicators of students' mathematical communication skills with rubek pengsekoran already provided. Problems prettes and postes are given in parallel. 
Hypothesis testing is done by using the real level of 0.05 . Prior to testing the hypothesis first tested data normality and homogeneity of variance. Hypothesis testing was performed by using two-track ANOVA test. All the tests performed assisted SPSS software.

\section{RESULTS AND DISCUSSION}

\section{Results}

The results of research for the ability of mathematical understanding are as follows:

Table 1. Analysis of Postes and N-Gain Data for Achievement and Improvement of Student Mathematical Problem Solving Ability

\begin{tabular}{|c|c|c|c|c|c|c|c|c|}
\hline \multirow[t]{2}{*}{$\begin{array}{l}\text { Variable } \\
\text { s }\end{array}$} & \multirow[t]{2}{*}{$\begin{array}{l}\text { Teaching } \\
\text { approach }\end{array}$} & \multirow[t]{2}{*}{$\begin{array}{l}\text { Normality } \\
\text { Test (Sig.) }\end{array}$} & \multirow[t]{2}{*}{$\begin{array}{l}\text { Homogenity } \\
\text { Test (Sig.) }\end{array}$} & \multicolumn{3}{|c|}{$\begin{array}{c}\text { Two Way Anova Test } \\
\text { (Sig.) }\end{array}$} & \multicolumn{2}{|c|}{ Interaction } \\
\hline & & & & $\begin{array}{l}\text { Metho } \\
\text { d }\end{array}$ & EAM & $\begin{array}{l}\text { Method } \\
* \text { EAM }\end{array}$ & $\begin{array}{l}\text { Sch } \\
\text { effe }\end{array}$ & Note \\
\hline \multirow[t]{2}{*}{$\begin{array}{l}\text { Postes } \\
\text { MPSA }\end{array}$} & $\begin{array}{c}\text { Metakogniti } \\
\text { ve }\end{array}$ & .063 & \multirow[t]{2}{*}{.613} & \multirow[t]{2}{*}{.008} & \multirow[t]{2}{*}{084} & \multirow[t]{2}{*}{.487} & \multirow[t]{2}{*}{-} & $\begin{array}{c}\text { Not } \\
\text { availabl }\end{array}$ \\
\hline & $\begin{array}{c}\text { Conventiona } \\
1\end{array}$ & .233 & & & & & & $\mathrm{e}$ \\
\hline \multirow[t]{2}{*}{$\begin{array}{l}\text { N-Gain } \\
\text { MPSA }\end{array}$} & $\begin{array}{l}\text { Metakogniti } \\
\text { ve }\end{array}$ & .087 & \multirow[t]{2}{*}{.613} & \multirow[t]{2}{*}{.012} & \multirow[t]{2}{*}{.077} & \multirow[t]{2}{*}{.491} & \multirow[t]{2}{*}{-} & $\begin{array}{c}\text { Not } \\
\text { availabl }\end{array}$ \\
\hline & $\begin{array}{c}\text { Conventiona } \\
1 \\
\end{array}$ & .199 & & & & & & e \\
\hline
\end{tabular}

Ket $:$ MPSA = Mathematical Problem Solving Ability

$\mathrm{EAM}=$ Early Ability of Mathematic

The above table explains that the achievement and improvement of problem solving abilities of mathematic students whose learning using metacognitive approach is better than students who use regular learning in terms of the initial ability of their students and there is no interaction between metacognitive approach and student's early ability in producing problem solving ability of mathematics.

In the results of this study metacognitive approach plays a role in the achievement and improvement of problem solving skills of mathematics, students' early ability is not so instrumental in achieving and improving students problem solving abilities of mathematics.

Seen in the table there is no interaction between the learning method with the initial ability of students in generating students problem solving abilities of mathematics then not proceeded to the Scheffe Test.

Meanwhile, the results of research for mathematical communication ability are as follows:

Table 1. Analysis of Postes and N-Gain Data for Achievement and Improvement of Student Mathematical Connection Ability

\begin{tabular}{|c|c|c|c|c|c|c|c|c|}
\hline \multirow[t]{2}{*}{$\begin{array}{c}\text { Variable } \\
\text { s }\end{array}$} & \multirow[t]{2}{*}{$\begin{array}{l}\text { Teaching } \\
\text { approach }\end{array}$} & \multirow[t]{2}{*}{$\begin{array}{l}\text { Normality } \\
\text { Test (Sig.) }\end{array}$} & \multirow[t]{2}{*}{$\begin{array}{l}\text { Homogenity } \\
\text { Test (Sig.) }\end{array}$} & \multicolumn{3}{|c|}{$\begin{array}{c}\text { Two Way Anova Test } \\
\text { (Sig.) }\end{array}$} & \multicolumn{2}{|c|}{ Interaction } \\
\hline & & & & $\begin{array}{l}\text { Metho } \\
\text { d }\end{array}$ & EAM & $\begin{array}{l}\text { Method } \\
* \text { EAM }\end{array}$ & $\begin{array}{l}\text { Sch } \\
\text { effe }\end{array}$ & Note. \\
\hline Postes & Metakogniti & .078 & .092 & .002 & .182 & .232 & - & Not \\
\hline
\end{tabular}


48 Sopian, A., Subandar, J. Improving The Ability Of Mathematic Problem Solving, Mathematic Connection And Self Regulated Learning with junior high School Students Through Metakognitive Approach.

\begin{tabular}{|c|c|c|c|c|c|c|c|c|}
\hline \multirow[t]{2}{*}{ MCA } & ve & & & & & & & \multirow{2}{*}{$\begin{array}{c}\text { availabl } \\
\mathrm{e}\end{array}$} \\
\hline & $\begin{array}{c}\text { Conventiona } \\
1\end{array}$ & .651 & & & & & & \\
\hline \multirow[t]{2}{*}{$\begin{array}{l}\text { N-Gain } \\
\text { MCA }\end{array}$} & $\begin{array}{l}\text { Metakogniti } \\
\text { ve }\end{array}$ & .065 & \multirow[t]{2}{*}{.092} & \multirow[t]{2}{*}{.032} & \multirow[t]{2}{*}{.211} & \multirow[t]{2}{*}{.772} & \multirow[t]{2}{*}{-} & \multirow{2}{*}{$\begin{array}{c}\text { Not } \\
\text { availabl } \\
\mathrm{e}\end{array}$} \\
\hline & $\begin{array}{c}\text { Conventiona } \\
1\end{array}$ & .222 & & & & & & \\
\hline
\end{tabular}

Note: $\mathrm{MCA}=$ Mathematical Connection Ability

$\mathrm{EAM}=$ Early Ability of Mathematic

Based on the results of the above table shows that the achievement and improvement of mathematical connection ability of students whose learning using metacognitive approach is better than students who use regular learning in terms of initial ability of students and there is no interaction between the metacognitive approach and the initial ability of students in generating mathematical connection ability.

The metacognitive approach plays a role in the attainment and improvement of problem solving abilities of mathematics whereas the early ability of the students does not play a role in the achievement and improvement of students' mathematical connection ability.

In the table there is no interaction between the learning method with the initial ability of students in generating students' mathematical connection ability is not continued to the Scheffe Test.

The results of the study for student self-reliance are as follows:

Table 3. Analysis Student Self Regulated Learning Scale

\begin{tabular}{ccccc}
\hline Vareavble & $\begin{array}{c}\text { Teaching } \\
\text { approach }\end{array}$ & $\begin{array}{c}\text { Normality } \\
\text { Test (Sig.) }\end{array}$ & $\begin{array}{c}\text { Homogenity } \\
\text { Test (Sig.) }\end{array}$ & $\begin{array}{c}\text { Independent } \\
\text { Sample t Test } \\
\text { (Sig) }\end{array}$ \\
\hline $\begin{array}{c}\text { Self } \\
\text { Regulated } \\
\text { Learning } \\
\text { Scale }\end{array}$ & $\begin{array}{c}\text { Metakogniti } \\
\text { ve }\end{array}$ & .067 & .712 & .021 \\
\hline
\end{tabular}

The table above shows that students 'learning independence using a metacognitive approach is better than students using ordinary learning in terms of students' initial ability

\section{Discussion}

Posttest result of mathematical problem solving ability in both sample classes after analyzed showed that postes in class with metacognitive approach higher than class with ordinary learning. In the ANOVA 2 test results, the postes score scores showed significant differences. So it can be concluded that the problem solving ability of mathematical students who get learning with metacognitive approach is better than students who get regular learning in terms of students' initial ability. The n-gain mean test shows that the improvement of students 'mathematical problem solving ability by using metacognitive approach is better than the students who get regular learning based on the students' initial ability. In line with the results of research conducted by (Permata et al., 2012) the results of his research mentioned that learning with metacognitive approach can improve the ability of problem solving 
mathematically. This explains that the metacognitive approach if implemented properly can improve students' mathematical problem solving skills.

The postes of mathematical connection ability in the two sample classes after being analyzed showed that postes in the classroom with metacognitive approaches were higher than those using the usual learning. The test results explain that postes score shows there are significant differences. So concluded that the ability of mathematical connection of students who get learning with metacognitive approach is better than students who get regular learning. N-gain mean test shows that the improvement of students' mathematical connection ability with learning using metacognitive approach is better than students who get regular learning. Better improvement with metacognitive approach indicates that learning with metacognitive approach has an effect on improving students' mathematical connection ability in terms of student's early ability. This is in line with research conducted by (Fauzi, 2011) which obtained the result of research that learning with metacognitive approach can improve students 'mathematical connection ability in terms of students' initial ability.

This improvement in problem solving and mathematical connections is not influenced by the student's early skills but the most influential is the metacognitive approach as seen in the previous discussion. In the result of the student's early ability analysis found that there is no difference between each level of students' initial ability. This affects the role of the student's early ability to improve the achievement of problem solving skills and mathematical connections of students. So that the initial ability of students does not play an important role in peninfkatan achievement of student's early ability.

The development of student self-reliance is seen in the learning class using the metacognitive approach used in the experimental class. Learning using metacognitive approaches can help students be more self-reliant in solving math problems and responsible for their actions, acting independently in making decisions about which strategies will be chosen in solving problems and having positive self-concept. In addition, learning by using metacognitive approach can help students dare to express opinions and have the impulse to excel and recognize the advantages and disadvantages themselves.

This is in line with some of the results of research conducted by (Fauzi, 2011) states that the independence of student learning in learning mathematics can be improved through metacognitive approach. This is because the stages contained in the approach metakognitis able to form student self-reliance.

Metacognitive approach is better used in learning, can train the independence of students and students have a high sense of responsibility in the effort to achieve the target of learning. Students are able to control their learning supported by a metacognitive approach that guides students trained to learn independently. Students are trained to become accustomed to finding mathematical problems, finding mathematical concepts, analyzing and summarizing their findings after which students are guided to do the problem with their own ability and are responsible for the findings.

In addition, students get guidance from the teacher if any unfinished parts are discussed in the group and not yet well understood. Teaching materials in the form of LKS used in learning are designed according to the metacognitive stage with the aim that students believe in their own abilities. The learning process that invites students to learn independently, then group and conclude the subject matter can help students learn with passion and seriously according to the procedures that exist on the metacognitive approach. So that the ability of connection and solving mathematical problems of students and the independence of student learning can develop well. 
50 Sopian, A., Subandar, J. Improving The Ability Of Mathematic Problem Solving, Mathematic Connection And Self Regulated Learning with junior high School Students Through Metakognitive Approach.

\section{CONCLUSION}

Based on the analysis of data and discussion presented in the previous Chapter, obtained some conclusions as follows:

1. Achievement and improvement of problem solving skills of junior high school students whose learning using metacognitive approach is better than students whose learning using ordinary learning is reviewed from the initial ability of the students.

2. The achievement and improvement of mathematical connection ability of junior high school students whose learning using metacognitive approach is better than the students whose learning using normal learning is viewed from the students' initial ability.

\section{REFERENCES}

Bergeson, T. (2000). Teaching and Learning Mathematics: Using Research to Shift From the "Yesterday" Mind to the "Tommorow" Mind. Retrieved from www.k12.wa.us

Fauzi, M. A. (2011). Peningkatan Kemampuan Koneksi Matematis Dan Kemandirian Belajar Siswa Dengan Pendekatan Pembelajaran Metakognitif di Sekolah Menengah Pertama. In International Seminar and the Fourth National Conference on Mathematics Education 2011 Department of Mathematics Education, Yogyakarta State University. Jogjakarta.

Fauziah, A. (2010). Peningkatan Kemampuan Pemahaman dan Pemecahan Masalah Matematik Siswa SMP Melalui Strategi React, Forum Kependidikan. Vol 30. 1, 1-13. Hariwijaya. (2009). Meningkatkan Kecerdasan Matematika. yogyakarta: Tugupublisher. NCTM. (2000). Principle and Strandars for School Mathematics. United States: NCTM.

Permata, S. P., Suherman, \& Rosha, M. (2012). Penerapan Strategi Metaognitif dalam Pembelajaran Matematika Siswa Kelas X SMA Negeri 2 Padang. Jurnal Pendidikan Matematika, 1, 8-13.

Russefendi, E. T. (2006). Pengantar Kepada Membantu Guru Mengembangkan

Kompetensinya dalam Pengajaran Matematika untuk Meningkatkan CBSA. Bandung: Tarsito.

Sugiono. (2013). Metode Penelitian Kombinasi (Mixed Methods). Bandung: Alfabeta. Sumarmo, U. (2006). Berpikir Matematika Tingkat Tinggi”. Makalah pada Seminar Pendidikan Matematika UNPAD. Bandung. 